Natural History at Aberdeen : Prof. V. C. WynneEdwards

Prof. V. C. Wynne-Edwards, who has been appointed to succeed Prof. A. C. Hardy in the regius chair of natural history in the University of Aberdeen, will bring a fresh point of view to the study of zoology in Great Britain. $\mathrm{He}$ is primarily a naturalist, but having trained in Oxford under the late Prof. E. S. Goodrich, he has a full understanding of the problems of general zoology. After taking his degree he worked for some time at Plymouth, mainly on herrings, and then for a while at the University of Bristol, but his reputation has mainly been made in Canada, in the Department of Zoology of McGill University. His earlier interest was in birds, and while in Britain he published papers on the behaviour of starlings, nightjars and other subjects. For several years he made a careful study of the habits and migrations of sea birds, and for this purpose once made no fewer than eight trans-Atlantic crossings in one summer. In Canada, his work has extended to the whole fauna and flora especially of the St. Lawrence region, and he has demonstrated that the groups of arctic plants found in this area cannot be relics of areas left unglaciated during the last ice-age. His great power of observation and ability to stimulate that of others will provide a refreshing new influence in Britain. We may hope that he will show the zoologists of this country, as he has those of Canada, how much can be seen by anyone who has the energy to move about in the country.

\section{Geological Society of London: Awards}

THE following awards have recently been made by the Geological Society: Wollaston Medal to M. Emmanuel de Margerie, honorary professor in the University of Strasbourg and formerly head of the Service géologique d'Alsace et de Lorraine, in recognition of his researches "on the Mineral Structure of the Earth", especially in the Jura Mountains of France, and for his bibliographical work; Murchison Medal to Dr. Leonard Hawkes, head of the Geological Department of Bedford College and reader in geology in the University of London, for his researches on Icelandic geology and on rocks in the glassy state; Lyell Medal to Dr. R. H. Rastall, for his researches into the petrology and structure of the Mesozoic rocks of eastern Eingland and for his editorship of the Geological Magazine; Wollaston Fund to Mr. James L. Begg, of Glasgow, for his studies on the geology and palæontology of the Lower Palæozoic rocks of the Girvan district; Murchison Fund to Dr. Alan Wood, demonstrator in geology in the Imperial College of Science and Technology, for his palæontological researches, notably on Carboniferous faunas and the evolution of the Foraminifera. Lyell Fund: one moiety to Dr. William Pulfrey, of the Mining and Geological Department, Kenya Colony, for his work on Palæozoic sediments of North Wales and on the Kavirondo area of Kenya Colony; another moiety to Mr. Percy T. Cox, for his researches on the Cretaceous Foraminifera and on the stratigraphy of the Persian Gulf.

\section{Naphthalene and the Dye Industry in Britain}

During the ten years 1886-96, the late Prof. H. E. Armstrong and Prof. W. P. Wynne were engaged, at the Central Technical College, London, in a series of researches which served to establish on a sure basis the structure of the large number of new naphthalene derivatives which were at that time being produced by empirical methods and were attracting the attention of chemists in the rapidly developing dye industry. Armstrong and Wynne completed the work of identification of all of the isomeric di- and tri-chloronaphthalenes, estab. lishing the orientation of the chlorine atoms in the naphthalene ring for every one of them. These compounds have been used as reference compounds for the establishment of the orientation of other naphtha. lene derivatives of unknown structure. This work was, of course, fundamental for naphthalene chemistry and has come to be regarded as classic. There can, however, be fow classical chemical researches which have been so inadequately reported in the literature as this work of Armstrong and Wynne. No connected account of it exists, the results of the work being recorded only in the briefest manner in the form of summaries of verbal communications to the Chemical Society printed in the Proceedings of that Society, and in the Chemical News.

Fortunately, however, a record of a different kind is available, for Prof. Wynne has preserved with meticulous care samples of the compounds prepared in the course of the research. Thus the actual samples of all the di- and tri-chloronaphthalenes, prepared, most of them, by several different routes, are available, in addition to the intermediate products of all kinds, such as chloronaphthols, mono-, di- and tri-chloronaphthalene sulphonic acids and chlorides, naphthylamine sulphonic acids, and many others which were made in the course of the work. During the years of his retirement, working in the University of Cambridge Chemical Laboratories, Prof. Wynne has given much attention to this collection, filling in gaps and perfecting it. This beautiful collection of some 465 specimens has now been presented by Prof. Wynne to the Dyestuffs Division of Imperial Chemical Industries, Ltd. The gift is more than a museum piece of historical interest, or even a collection of reference samples; it is a constant reminder of the debt which industry owes to the work of disinterested academic scientific workers. It has been accepted by the Company with the greatest pleasure and gratitude, and is to occupy a place of honour in the Research Department.

\section{ASLIB Microfilm Service}

To meet war-time difficulties, the Association of Special Libraries and Information Bureaux, with the help of the Royal Society, the Rockefeller Foundation and British industry, organised a microfilm service which started operations in April 1942 and which supplied, in microfilm or paper enlargements, copies of scientific and technical periodicals pub. lished in Germany and countries occupied by Germany during the war years. The service was used by the British and American Governments, by more than three hundred scientific institutions and research stations in Great Britain and the Empire and, under a special agency arrangement, by several hundred institutions in the United States. The library of master negatives accumulated for the purpose contains some 14,000 separate issues of approximately 500 different titles, equivalent to a total of more than a million pages. On behalf of the British Council, microfilm copies of British periodicals were prepared for China when that country was cut off from ordinary surface transport; this work grew, until in 1945 some 170 periodicals were regularly microfilmed and six positive copies of each were dispatched to China by air. 